\title{
Effects of imidacloprid-sodium chloride association on survival and reproduction of the stink bug Podisus nigrispinus
}

\author{
Efectos de la asociación de imidacloprid-cloruro de sodio en la supervivencia y \\ reproducción del chinche Podisus nigrispinus
}

\author{
Gabryele Silva Ramos ${ }^{1}$, Paula Daiana de Paulo ${ }^{2}$, Pedro F. S. Toledo ${ }^{3}$, Khalid Haddi ${ }^{4 \dagger}$, \\ Jose Cola Zanuncio ${ }^{5}$, Eugenio E. Oliveira ${ }^{6}$
}

\begin{abstract}
ARTICLE DATA
1 Ph.D. Plant Protection Departament. Universidade Estadual de São Paulo, Botucatu, SP, Brasil. gabryele.sr@gmail.com

2 Ph.D. Entomology Departament. Universidade Federal de Viçosa, Viçosa, MG, Brasil. paula.paulo@ ufv.br

3 MSc. Entomology Departament, Universidade Federal de Viçosa, Viçosa, MG, Brasil. pedro. toledo@ufv.br

${ }^{4 \dagger}$ Dr. Entomology Departament, Universidade Federal de Lavras, Lavras, MG, Brasil. khalid. haddi@ufla.br

5 Ph.D. Entomology Departament, Universidade Federal de Viçosa, Viçosa, MG, Brasil. zanuncio@ ufv.br

6 Ph.D. Entomology Departament, Universidade Federal de Viçosa, Viçosa, MG, Brasil.eugenio@ufv.br
\end{abstract}

Cite: Ramos, G., De Paulo, P., Toledo, P., Haddi, K., Zanuncio, J., Oliveira, E. (2019). Effects of imidacloprid-sodium chloride association on survival and reproduction of the stink bug Podisus nigrispinus. Revista de Ciencias Agrícolas. 36(E): 71-81. doi: https:// doi.org/10.22267/rcia.1936E.108

Received: October 102019.

Accepted: October 202019.

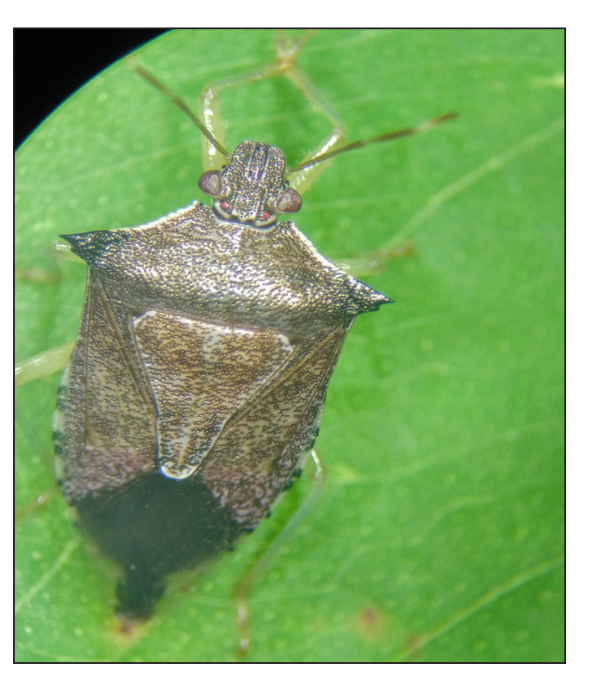

ABSTRACT

Pesticide effects on natural enemies in an agroecosystem are of paramount importance for integrated pest management programs. Natural enemies can be subject to direct and indirect exposure to insecticides and synergistic molecules (e.g., sodium chloride - $\mathrm{NaCl}$ ) which are used to control various pests of agricultural crops such as soybean. Here, we evaluated the potential effects of imidacloprid and its interaction with $\mathrm{NaCl}$ as an enhancer on the survival and reproductive abilities of the non-target predator Podisus nigrispinus (Dallas) (Hemiptera: Pentatomidae). The insects were exposed to the stink bugs control field recommended dose of imidacloprid associated or not with the salt at the concentration of $0.5 \%(\mathrm{w} / \mathrm{v}) . \mathrm{NaCl}$ as a pesticide enhancer did not affect the survival of P. nigrispinus adults after $48 \mathrm{~h}$ of exposure (less than $12 \%$ of mortality was always recorded). However, the fifth instar nymph mortality was almost $50 \%$. The effects of imidacloprid on the reproductive parameters of $P$. nigrispinus included a decrease in the oviposition, showing fewer eggs per day. However, the fertility was not affected. The $\mathrm{NaCl}$ addition, therefore, had no effect on the mortality, survival, and reproduction of the non-target predator. The use of $\mathrm{NaCl}$ associated to imidacloprid and other pesticides in the presence of P. nigrispinus demonstrated compatibility, however, it requires further evaluation to endorse the set of these pest control strategies.

Keywords: Asopinae, biological control, ecotoxicology, IPM, pest control, selectivity.

\section{RESUMEN}

Los efectos de los pesticidas sobre los enemigos naturales en un agroecosistema son de suma importancia para los programas de manejo integrado de plagas. Los enemigos naturales pueden estar sujetos a la exposición directa e indirecta de insecticidas y moléculas sinérgicas (por ejemplo, cloruro de sodio - $\mathrm{NaCl}$ ) que se utilizan para controlar diversas plagas de cultivos agrícolas como la soja. Aquí, evaluamos los posibles efectos del imidacloprid y su interacción con $\mathrm{NaCl}$ como un potenciador de la supervivencia y las capacidades reproductivas del depredador no objetivo Podisus nigrispinus (Dallas) (Hemiptera: Pentatomidae Los insectos fueron expuestos a una tasa de campo de imidacloprid, recomendado para controlar los chinches en campos de soya. La solución de imidacloprid fue mezclada (o no) con $\mathrm{NaCl}(0.5 \%$, w/v). El $\mathrm{NaCl}$ como potenciador de pesticidas no afectó la supervivencia de los adultos de P. nigrispinus después de 48 h de exposición (siempre se registró menos del 12\% de mortalidad). 
Ramos et al-. Imidacloprid-sodium chloride association on survival and reproduction Podisus nigrispinus.

\begin{abstract}
Sin embargo, la mortalidad de la ninfa del quinto estadio fue casi del 50\%. Los efectos de imidacloprid sobre los parámetros reproductivos de P. nigrispinus incluyeron una disminución en la oviposición, mostrando menos huevos por día. Sin embargo, la fertilidad no se vio afectada. La adición de $\mathrm{NaCl}$, por lo tanto, no tuvo efecto sobre la mortalidad, supervivencia y reproducción del depredador no objetivo. El uso de $\mathrm{NaCl}$ asociado a imidacloprid y otros pesticidas en presencia de P. nigrispinus demostró compatibilidad, sin embargo, requiere una evaluación adicional para respaldar el conjunto de estas estrategias de control de plagas.
\end{abstract}

Palabras clave: Asopinae, control biológico, ecotoxicología, MIP, control de plagas, selectividad.

\section{INTRODUCTION}

The soybean, Glycine $\max$ L., presents great economic importance in Brazil and the productivity of these plants is severely affected by insect pest attacks. These insects, besides decreasing productivity, substantially raise the cost of production due to pest management strategies which are of unquestioned need (Ávila and Grigolli, 2014; Peterson et al., 2018).

Among other insect pests, the herbivory attacks delivered by a "stink bug complex", which includes over three species of stink bugs, is considered one of the major barriers to the development of soybean crop fields in Brazil and other countries (Da Graça et al., 2016). The management of such pests, for instance, the Neotropical stink bug, Euchistus heros (Fabr.) (Hemiptera: Pentatomidae) heavily relies on the use of synthetic pesticides, which includes, organophosphates, pyrethroids, organochlorides (endosulfan) and neonicotinoids (Panizzi et al., 2012; Tuelher et al., 2018).

The neonicotinoids, acting as agonists of acetylcholine receptors (Buckingham et al., 1997; Nauen et al., 2001), are among the most used pesticides in soybean fields and are frequently used by Brazilian farmers due to their high efficiency (Pazini et al., 2019; Castellanos et al., 2019). Furthermore, a common practice in Brazilian soybean fields consisting of adding sodium chloride $(\mathrm{NaCl})$ at the concentration of $0.5 \%(\mathrm{w} / \mathrm{v})$ to insecticide solutions is, supposedly, believed to decrease the quantities of pesticide by half (50\%) without losing efficiency (Corso, 1990; Panizzi et al., 2007; Ávila and Grigolli, 2014).

It is believed that $\mathrm{NaCl}$ acts like a phagostimulant or arrestant molecule, which increases the insect contact (exposure period) with the pesticide solution or dry residues (Corso, 1990; Sosa-Gómez et al., 1993; Niva and Panizzi, 1996; Corso and Gazzoni, 1998). The existence of salt action on the pentatomid stink bugs nervous system was confirmed by the presence of neuroreceptors sensitive to low concentrations of sodium chloride, causing a simultaneous attraction (Gr5a receptors) and deterrence (Gr66a receptors) behavior (Yarmolinsky et al., 2009).

A couple of recent works tried to better elucidate the actions of imidacloprid (Haddi et al., 2016; Santos et al., 2016), but the synergic effects of $\mathrm{NaCl}$ added to some pesticides are not fully explained and still need further investigations that address the reasons underlying the aforementioned synergism as well as the reasons why it occurs only with some pesticides.

The use of biological control and integrated pest management programs in soybean fields, especially for the control of Anticarsia gemmatalis (Hübner, 1818) (Lepidoptera: Noctuidae), and some other stink bugs have also had favorable results (Ramiro et al., 1986). Predatory stink bugs, e.g., Podisus nigrispinus, Hemiptera: Pentatomidae, 
naturally occur in the Neotropical region (in many crop fields, including soybean) and are considered very important natural enemies of defoliator caterpillars (Pires et al., 2006, Holtz et al., 2019).

These predatory insects delivery their free of costs ecological services aiding in the management of soybean pests and have the potential to be introduced to enhance the power of other pest control strategies, in cases of augmentative biological control uses (Desneux et al., 2007; Batalha et al., 2012; He et al., 2012; Naranjo et al., 2015; Bueno et al., 2017). However, the impacts of commonly used conventional pesticides and their enhancers (e.g., $\mathrm{NaCl}$ ) have been completely neglected for predatory stink bugs. Hence, it is of extreme importance to study the potential selectivity/compatibility of these compounds to natural enemies.

Thus, this study aimed to investigate the potential effects including side effects on the reproductive abilities of the neonicotinoid imidacloprid associated to $\mathrm{NaCl}$ which is highly recommended for controlling the Neotropical stink bug E. heros on the predatory stink bug $P$. nigrispinus.

\section{MATERIAL AND METHODS}

\section{Insect rearing}

Podisus nigrispinus. Eggs of Podisus nigrispinus were field-collected and kept in Petri dishes $(9 \mathrm{~cm}$ diameter) with distilled water (soaked cotton wool) to provide humidity. After egg hatching, immature stages were transferred to cages $(30 \times 15 \mathrm{~cm})$ made by wood (frame) and veil cloth (coverage). They were fed with Tenebrio molitor L. (Coleoptera: Tenebrionidae) pupae. Additionally, Eucalyptus spp. leaves were provided by setting a small branch inside the cage. The stem of the branches was kept inside a glass flask (15 mL of volume capacity) filled with water to keep them hydrated. The stock colony was kept under controlled conditions of temperature $\left(25 \pm 2^{\circ} \mathrm{C}\right)$, photoperiod $(12 \mathrm{~h}$ scotophase), and humidity (70 $\pm 10 \%)$ (Lemos et al., 2003).

\section{Bioassays}

Acute toxicity against the predatory stink bug Podisus nigrispinus. Newly emerged fifth instar nymphs and adult females $(<72$ hours) were exposed to dry residues of the recommended field rate $\left(4.2 \mu \mathrm{g}\right.$ a.i. $\left./ \mathrm{cm}^{2}\right)$ of imidacloprid to control $E$. heros in soybean fields (MAPA, 2018) with or without the addition of $\mathrm{NaCl} 0.5 \%(\mathrm{w} / \mathrm{v})$. Distilled water added or not with $\mathrm{NaCl}$ was used as the control. Insecticide exposure was achieved by contact with glass surface impregnated with dried residues. Briefly, $2 \mathrm{~mL}$ of insecticide solution of distilled water were applied to $250 \mathrm{~mL}$ transparent glass jars (EME Equipment, Paulicéia, SP, Brazil), which were maintained under rotation until dry using a heavy-duty rotator (Roto-Torque model 7637, ColeParmer, Vernon Hills, IL, USA) to coat the inner walls of the jars with insecticide residue. The upper portion of each container was coated with Teflon PTFE (DuPont, Wilmington, DE, USA) to prevent insects from escaping. Ten insects, nymphs or adult females, were set inside the glass flasks and the exposure period was 48 hours. Insects were considered dead when did not move or cannot walk a distance corresponding to double the size of their own body for one minute. The experiments were kept under laboratory-controlled conditions of temperature $25 \pm 2{ }^{\circ} \mathrm{C}$ relative humidity $60 \pm 10 \%$ and L:D photoperiod of $14: 10 \mathrm{~h}$. Was performed at least nine replicates for each $P$. nigrispinus stage and treatment.

The survivor insects that came from the 48hour exposure were kept individualized in 
Petri dishes (diameter: $90 \mathrm{~mm}$ ) bottom-side covered with filter paper. Insects were fed with pupae of T. molitor, Eucalyptus spp. leaves (7cm stem containing three or four leaves) and distilled water (soaked cotton wool). The experiments were kept under laboratorycontrolled conditions of temperature 25 $\pm 2^{\circ} \mathrm{C}$ relative humidity $60 \pm 10 \%$ and L:D photoperiod of $14: 10 \mathrm{~h}$. Was performed 88 replicates each insect was considered one replicate.

Sublethal effects on the reproduction of Podisus nigrispinus females. Newly emerged adults of $P$. nigrispinus (24h) were exposed individually to dry residues of the recommended field rate $(4.2 \mu \mathrm{g}$ a.i./ $\mathrm{cm}^{2}$ ) of imidacloprid to control E. heros in soybean fields (MAPA, 2018) with or without the addition of sodium chloride at the concentration of $0.5 \%(\mathrm{~m} / \mathrm{v})$ as described earlier. Distilled water was added with sodium chloride or not as control treatments. After 48 hours of exposure, couples of this predator were formed and set in Petri dish (ø $90 \mathrm{~mm}$ x $15 \mathrm{~mm}$ of depth), fed every two days with one Eucalyptus spp. leaflet, two T. molitor pupae and distilled water on soaked cotton wools. Twelve replicates (each couple was considered one replicate) were performed per treatment. The number of eggs laid per female was daily evaluated and the eggs removed and placed in new Petri dishes with distilled water (soaked cotton wool) to provide humidity. The emergence of nymphs was also daily evaluated until the female death. The bioassay was kept under laboratory-controlled conditions of temperature $25 \pm 2^{\circ} \mathrm{C}$ relative humidity $60 \pm$ $10 \%$ and L:D photoperiod of 14:10h.

Statistical Analysis. The mortality data obtained were corrected for that occurred in the control treatment. The data were subject to a 1-way analysis of variance and when the assumptions of residual normality and variance homogeneity were not met, the mortality was subjected to Kruskal-Wallis test ate $5 \%$ probability. Survival analysis was subjected to Kaplan-Meier test (LogRank method) and the reproductive parameters data (daily egg and nymphs numbers) were respectively submitted to Tukey and KruskallWallis tests $(\mathrm{P}<0.05)$ using SigmaPlot version 12.5 software (Systat Software, San Jose, CA, USA).

\section{RESULTS AND DISCUSSION}

Toxicity to the fifth instar of Podisus nigrispinus. The exposure of fifth instar nymphs of $P$. nigrispinus to $4.2 \mu \mathrm{g}$ a.i. $/ \mathrm{cm}^{2}$ (which is equivalent to the recommended field rate to control $E$. heros) with or without the addition of $\mathrm{NaCl}$ differed from the control group $(\mathrm{H}=21.35 ; P<0.001)$. Nymph mortality occasioned by the neonicotinoid imidacloprid (associated or not to $\mathrm{NaCl}$ ) was lower than $50 \%$. The average mortalities by treatments with the field dose and the field dose plus salt were $36.3 \pm 13.49 \%$ and $42.3 \pm 14.38 \%$, respectively. Treatments containing only water and water plus salt $(0.5 \% \mathrm{c} / \mathrm{c})$ caused mortality of $5.7 \pm 0.07 \%$ and $10.1 \pm 0.08 \%$, respectively (Figure $1 A$ ).

Toxicity to adult females of Podisus nigrispinus. The mortality rate of adult females of $P$. nigrispinus exposed to $4.2 \mu \mathrm{g}$ a.i. $/ \mathrm{cm}^{2}$ of imidacloprid (associated or not to $\mathrm{NaCl}$ ) did not differ from the control group ( $H=2.3 ; P=0.51)$. Mortality of adult females of $P$. nigrispinus was lower than $12 \%$ in all treatments. The mortality average in the treatments containing the field dose and the field dose plus salt was $9.0 \pm 4.65 \%$ for both. Treatment containing only water caused mortality of $6.3 \pm 2.42 \%$ and water plus salt $(0.5 \%$ c/c) $4.8 \pm 2.42 \%$ (Figure $1 B$ ). 
A

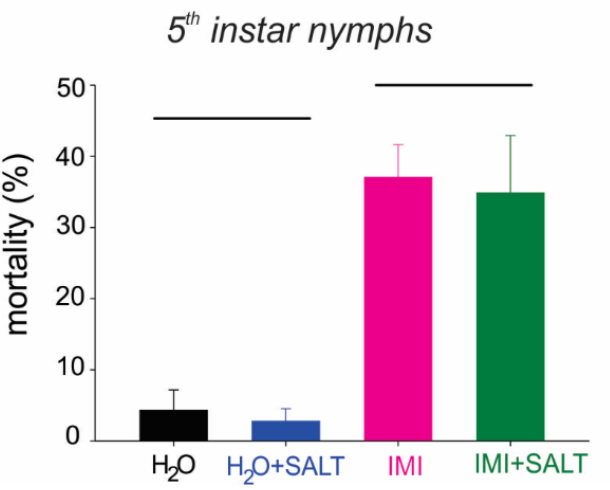

B

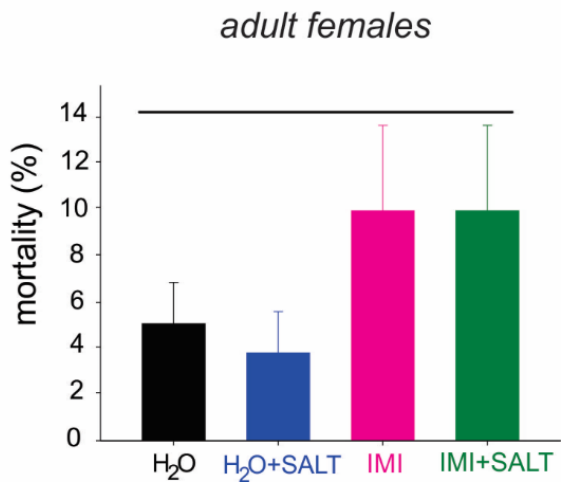

Figure 1. Mortality of fifth instar nymphs (A) and adult females (B) of Podisus nigrispinus after 48-hour of exposure to $4.2 \mu \mathrm{g}$ a.i. $/ \mathrm{cm}^{2}$ of imidacloprid (associated or not to $\mathrm{NaCl}$ ).

Survival of exposed Podisus nigrispinus. Survival of $P$. nigrispinus adults did not differ between unexposed and imidaclopridexposed insects ( $\log$ Rank $=7.5 ; P=0.06$ ). The median survival time ranged from 15.1 to 20.7 days. The survival averages of $P$. nigrispinus adults were $20.7 \pm 2.43$; $20.3 \pm 2.24 ; 16.1 \pm 1.4$ and $14.9 \pm 0.98$ days in the treatments using the field dose of imidacloprid, imidacloprid with the salt addition, only water and water with salt $(0.5 \% \mathrm{w} / \mathrm{v})$, respectively (Figure 2$)$.

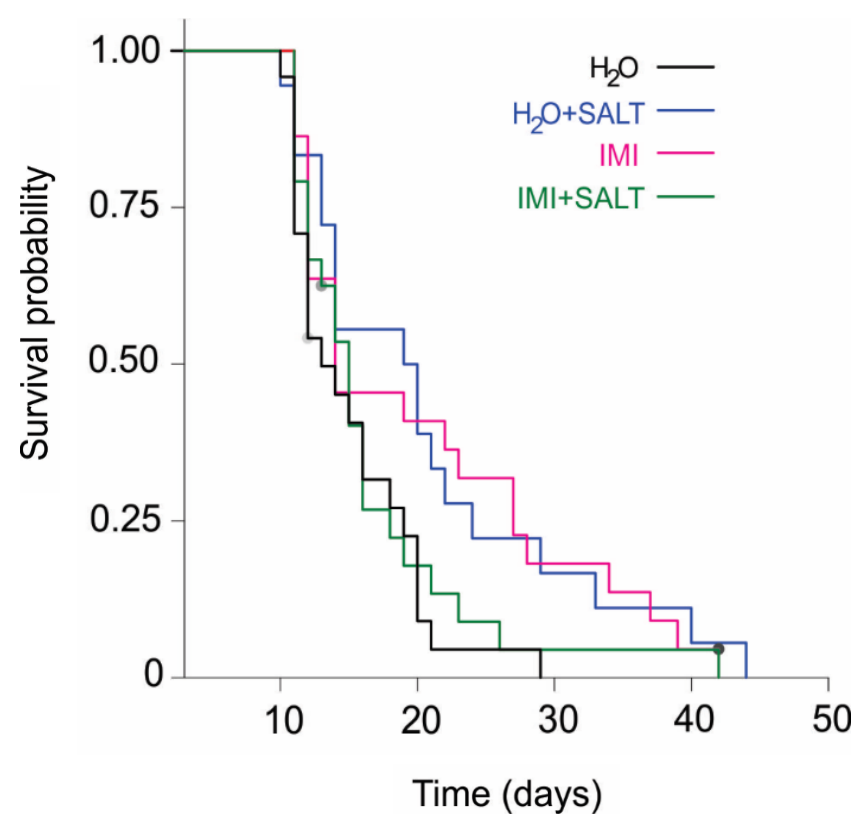

Figure 2. Survival curves of Podisus nigrispinus adults after 48 hours of exposure to $4.2 \mu \mathrm{g}$ a.i. $/ \mathrm{cm}^{2}$ of imidacloprid (associated or not to $\mathrm{NaCl}$ ) using the Kaplan-Meier method and compared using the logrank test ( $\left.\log \operatorname{Rank}_{d f=3}=7.51 ; P=0.057\right)$. 
Sublethal effects on the reproduction of Podisus nigrispinus females. Fecundity and fertility of P. nigrispinus females were similar between treatments without insecticide (Figures 3 and 4). On the contrary, imidacloprid associated or not to $\mathrm{NaCl}$ reduced the total (Figure $3 A$ ) and daily
(Figure $3 B$ ) fertility of this natural enemy $(H$ $=21.4 ; P<0.001$ ). This reduction in fecundity caused by the pesticide exposure affected the total (Figure $4 A$ ) and daily nymph hatching (Figure $4 B$ ) which differed from the control with water $(H=9.80 ; P=0.014)$ and water plus salt $(H=9.80 ; P=0.016)$.
A

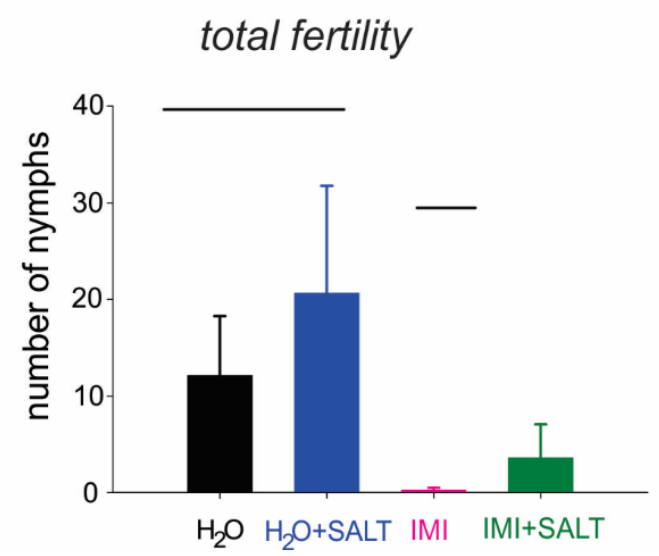

B

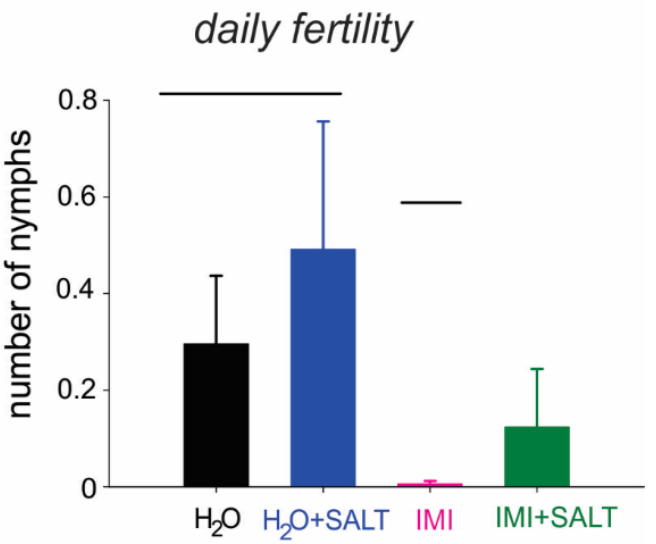

Figure 3. Fertility of adult females of Podisus nigrispinus after 48-hour exposure to $4.2 \mu \mathrm{g}$ i.a. $/ \mathrm{cm}^{2}$ of imidacloprid (associated or not to $\mathrm{NaCl}$ ). (A) Fertility graphic based on the total number of eggs and (B) Fertility graphic of daily number of eggs hatched.

A

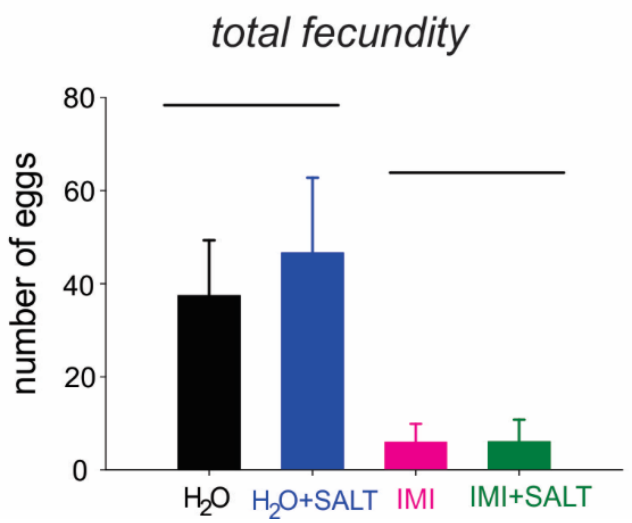

B

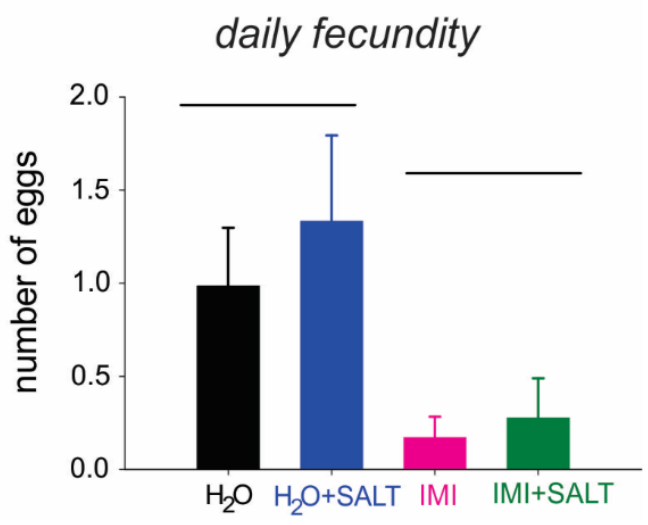

Figure 4. Fecundity of Podisus nigrispinus adults after 48 hours of exposure to $4.2 \mu \mathrm{g}$ i.a. $/ \mathrm{cm}^{2}$ of imidacloprid (associated or not to $\mathrm{NaCl}$ ). (A) Fecundity graphic of total nymphs' number hatched and (B) Fecundity graphic of daily nymphs' number hatched. 
Studying the potential impacts of conventional pesticides and their synergists (e.g., $\mathrm{NaCl}$ ) against beneficial organisms is of unquestioned need. Although neonicotinoid insecticides have been thriving on the market due to their power to control insect pests, they have received attention regarding their side effects on non-target organisms e.g., pollinating bees and natural enemies and it becomes a more pessimistic scenario in the presence of pesticide enhancers.

In the present study, we have demonstrated that imidacloprid solutions (regardless of salt addition) increased the mortality of fifth instar nymphs of the predatory stink bug $P$. nigrispinus. On the other hand, those pesticide solutions neither caused mortality nor affected the survival of $P$. nigrispinus adults. A higher survival of $P$. nigrispinus adults compared to its nymphal stages fourth and fifth instars after exposure to pesticides such as imidacloprid, pyriproxyfen and neem oil has been demonstrated elsewhere (Zanuncio et al., 2016). The increased susceptibility of insect immature stages may reflect a lower concentration of detoxifying enzymes (esterases) as well as the cuticle composition (Guedes et al., 1992; Zanuncio et al., 2001). Hence, our results reinforced that immature stages of this predatory stink bug are more susceptible to pesticides .

The mixture of thiamethoxan, cypermethrin, and $\mathrm{NaCl}$ as an enhancer allowed the control of Piezodorus guildinii, Nezara viridula and $E$. heros species for longer periods (up to 15 days) (Ramiro et al., 2005). The $\mathrm{NaCl}$ is a synergistic agent in insecticide solutions due to the preference of pest insects for areas treated with low $\mathrm{NaCl}$ concentrations (Corso and Gazzoni, 1998; Marcomini et al., 2016). This synergist causes shifts on the behavior of insect pests through an arresting effect which makes them more dynamic on the plant, increasing insect exposure to insecticides
(Corso et al., 1990). These effects may result of a neuronal response in the expression of Gr5a receptors stimulated on the presence of low $\mathrm{NaCl}$ concentrations and Gr66a which results in aversion to $\mathrm{NaCl}$ (Yarmolinsky et al., 2009). Such response may be absent in $P$. nigrispinus due to its different life history traits the differential confirmation of its site of action, as well as the presence of tarsal sensilla that may alter the toxicodynamic of the $\mathrm{NaCl}$ (Focks et al., 2018).

Toxic effects caused by imidacloprid may affect the nutrient uptake, disaggregation, digestive physiology and reproductive abilities and behavior of the non-target predator (Magalhães et al., 2002; Malaquias et al., 2014; Martínez et al., 2019). The neonicotinoids had been reported as molecules that did not affect the oviposition and egg hatch of treated female adults of Podisus sp. and showing lower mortality and survival impacts compared with to residual toxicity of pyrethroid molecules (De Cock et al., 1996; Tillman and Mullinix, 2004; Torres and Ruberson, 2004; Pereira et al., 2005). These results suggest that the viability of the eggs was not affected by the imidacloprid with or without salt but the fertility of this predator was reduced in agreement with results for pesticides reducing mature oocytes and increasing the maturation period of P. nigrispinus (Reis et al., 2018).

The use of salt as a synergist favors a reduction in the amount of insecticide applied to soybean crops, reducing the farms expenditure on inputs (i.e., increasing profit), as well as causing a lower environmental impact. Interestingly, the addition of the enhancer (i.e., $\mathrm{NaCl}$ ) did not impact any of the parameters evaluated here for $P$. nigrispinus. The fecundity data show that the non-target predator is susceptible to imidacloprid, but not to the addition of salt. The treatments that contained the field dose 
Ramos et al-. Imidacloprid-sodium chloride association on survival and reproduction Podisus nigrispinus.

of this insecticide presented lower number of nymphs compared to that with water or water with salt. Even though imidacloprid increases the mortality and impacts the fertility and fecundity of $P$. nigrispinus, the addition of $\mathrm{NaCl}$ which supposedly increase the strength of pesticides against stink bug pests did not impact the evaluated parameters. Sublethal doses of imidacloprid showed effects on the medium intestine of $P$. nigrispinus, affecting severally the digestion capacity consequently the predatory potential (Martínez et al., 2019).

\section{CONCLUSIONS}

In summary, we assessed the lethal effects of the field dose of imidacloprid (with and without association with $\mathrm{NaCl}$ ) used to control E. heros towards the pentatomid predator $P$. nigrispinus. Therefore, the synergistic agent $\mathrm{NaCl}$ may be used against pests in the presence of $P$. nigrispinus as the ingestion of this Asopinae predator was not affected by the salt but sublethal effects deserves attention. Thus, our results reinforce that the tandem use of $\mathrm{NaCl}$ as an enhancer with imidacloprid do not increase the problems associated with the pesticide against the predatory stink bug, P. nigrispinus. However, this interaction should be carefully investigated to endorse its use in more sustainable soybean IPM programs.

\section{ACKNOWLEDGMENT}

To the Brazilian agencies "Conselho Nacional de Desenvolvimento Científico e Tecnológico (CNPq)", Coordenação de Aperfeiçoamento de Pessoal de Nível Superior (CAPES- Finance Code 001)", "Fundação de Amparo à Pesquisa do Estado de Minas Gerais (FAPEMIG)", and "Programa Cooperativo sobre Proteção Florestal (PROTEF) do Instituto de Pesquisas e Estudos Florestais (IPEF)" for finantial support.
Conflict of interest: The authors declare that they have no conflict of interest.

\section{BIBLIOGRAPHIC REFERENCES}

Ávila, C.B. \& Grigolli, J.F.J. (2014) Pragas de soja e seu controle. Tecnologia e Produção: Soja 2013/2014. Fundação MS. Recovered from http://www.fundacaoms.org.br/tecnologiaproducao-soja-2013-2014.

Batalha, V.C., Zanuncio, J.C., Picanco, M. \& Guedes, R.N.C. (2012). Selectivity of insecticides to Podisus nigrispinus (Heteroptera: Pentatornidae) and its prey Spodoptera frugiperda (Lepidoptera: Noctuidae). Ceiba, 38(1), 19-22.

Buckingham, S., Lapied, B., Corronc, H. \& Sattelle, F. (1997). Imidacloprid actions on insect neuronal acetylcholine receptors. The Journal of Experimental Biology, 200(Pt 21), 26852692. Recovered from http://www.ncbi.nlm. nih.gov/pubmed/9326496.

Bueno, A. de F., Carvalho, G.A., Dos Santos, A.C., Sosa-Gómez, D.R. \& Da Silva, D.M. (2017). Pesticide selectivity to natural enemies: challenges and constraints for research and field recommendation. Ciência Rural, 47(6): 2-10. doi: https://doi.org/10.1590/01038478 cr20160829

Castellanos, N.L., Haddi, K., Carvalho, G.A., De Paulo, P.D., Hirose, E., Guedes, R.N.C., Smagghe, G. \& Oliveira, E.E. (2019). Imidacloprid resistance in the Neotropical brown stink bug Euschistus heros: selection and fitness costs. Journal of Pest Science, 92(2): 847-860. doi: https://doi.org/10.1007/s10340-018-1048-z

Corso, I.C. (1990). Uso do sal de cozinha na redução da dose de inseticida para controle de percevejos. Embrapa Soja - Comunicado Técnico (INFOTECA-E), 7p. Recovered from https://www.infoteca.cnptia.embrapa.br / infoteca/bitstream/doc/445306/1/45.pdf

Corso, I.C. \& Gazzoni, D.L. (1998). Sodium chloride: An insecticide enhancer for controlling pentatomids on soybeans. Pesquisa Agropecuaria Brasileira, 33(10): 1563 - 1571. 
Da Graça, J.P., Ueda, T.E., Janegitz, T., Vieira, S.S., Salvador, M.C., De Oliveira, M.C.N., Zingaretti, S.M., Powers, S.J., Pickett, J.A., Birkett, M.A. \& Hoffmann-Campo, C. B. (2016). The natural plant stress elicitor cis-jasmone causes cultivardependent reduction in growth of the stink bug, Euschistus heros and associated changes in flavonoid concentrations in soybean, Glycine max. Phytochemistry, 131: 84-91. doi: https:// doi.org/10.1016/j.phytochem.2016.08.013.

De Cock, A., De Clercq, P., Tirry, L. \& Degheele, D. (1996). Toxicity of Diafenthiuron and Imidacloprid to the Predatory Bug Podisus maculiventris (Heteroptera: Pentatomidae). Environmental Entomology. 25(2): 476-480. doi: https://doi.org/10.1093/ee/25.2.476.

Desneux, N., Decourtye, A. \& Delpuech, J.M. (2007). The Sublethal Effects of Pesticides on Beneficial Arthropods. Annual Review of Entomology. 52(1): 81-106. doi: https://doi.org/10.1146/ annurev.ento.52.110405.091440.

Focks, A., Belgers, D., Boerwinkel, M.C., Buijse, L., Roessink, I. \& Van den Brink, P.J. (2018). Calibration and validation of toxicokinetictoxicodynamic models for three neonicotinoids and some aquatic macroinvertebrates. Ecotoxicology. 27(7): 992-1007. doi: https:// doi.org/10.1007/s10646-018-1940-6.

Guedes, R.N.C., Lima, J.O.G. \& Zanuncio, J.C. (1992) Seletividade dos inseticidas deltametrina, fenvalerato e fenitrotiom para Podisus connexivus Bergroth, 1891 (Heteroptera: Pentatomidae). Anais da Sociedade Entomologica do Brasil, 21: 339-346.

Haddi, K., Mendes, M.V., Barcellos, M.S., LinoNeto, J., Freitas, H.L., Guedes, R.N.C. \& Oliveira, E. E. (2016). Sexual Success after stress? Imidacloprid-Induced Hormesis in Males of the Neotropical Stink Bug Euschistus heros. PLoS ONE, 11(6):e0156616. doi: https://doi. org/10.1371/journal.pone.0156616.

He, Y., Zhao, J., Zheng, Y., Desneux, N. \& Wu, K. (2012). Lethal effect of imidacloprid on the coccinellid predator Serangium japonicum and sublethal effects on predator voracity and on functional response to the whitefly Bemisia tabaci. Ecotoxicology, 21(5): 12911300. doi: https://doi.org/10.1007/s10646012-0883-6.
Holtz, A.M., Marinho-Prado, J.S., Pallini, A., Pires, A.A., Cofler, T.P., Rocha, C.M., \& Pazianotto, R.A.A. (2019). Host plant and the predator Podisus nigrispinus: when the defense compounds of the plant affect the third trophic level. Entomologia Experimentalis et Applicata. 167(4): 306 -312. doi: https://doi. org/10.1111/eea.12774

Lemos, W.P., Ramalho, F.S., Serrao, J.E. \& Zanuncio, J.C. (2003). Effects of diet on development of Podisus nigrispinus (Dallas) (Het., Pentatomidae), a predator of the cotton leafworm. Journal of Applied Entomology. 127(7): 389 - 395. doi: https://doi. org/10.1046/j.1439-0418.2003.00765.x

Magalhães, L.C., Guedes, R.N.C., Oliveira, E.E., \& Tuelher, E.S. (2002). Desenvolvimento e Reprodução do Predador Podisus distinctus (Stal) (Heteroptera: Pentatomidae) frente a doses subletais de permetrina. Neotropical Entomology. 31(3): 445-448. doi: https://doi. org/10.1590/S1519-566X2002000300015.

Malaquias, J.B., Ramalho, F.S., Omoto, C., Godoy, W.A.C. \& Silveira, R.F. (2014). Imidacloprid affects the functional response of predator Podisus nigrispinus (Dallas) (Heteroptera: Pentatomidae) to strains of Spodoptera frugiperda (J.E. Smith) on Bt cotton. Ecotoxicology, 23(2): 192-200. doi: https:// doi.org/10.1007/s10646-013-1162-x.

Marcomini, M.C., Cremonez, P.S.G \& Neves, P.M.O.J. (2016). Efeito do $\mathrm{NaCl}$ no comportamento alimentar de Euschistus heros (Hemiptera: Pentatomidae). Anais Do Encontro Anual De Iniciação Científica Da UEL - ISSN 2447-4118. Recovered from http://www.uel.br/eventos/ eaic/anais $/$ ?content $=2016 /$ anais_resumo. php\&cod_artigo $=564$.

Martínez, L.C., Plata-Rueda, A., Gonçalves, W.G., Freire, A.F.P.A., Zanuncio, J.C., Bozdoğan, H. \& Serrão, J.E. (2019). Toxicity and cytotoxicity of the insecticide imidacloprid in the midgut of the predatory bug, Podisus nigrispinus. Ecotoxicology and Environmental Safety, 167: 69 - 75. doi: https://doi.org/10.1016/j. ecoenv.2018.09.124.

Ministério Da Agricultura, Pecuária E Abastecimento - MAPA. (2018). AGROSTAT - Estatísticas de Comércio Exterior do 
Ramos et al-. Imidacloprid-sodium chloride association on survival and reproduction Podisus nigrispinus.

Agronegócio Brasileiro. Recovered from http:// agrostat.agricultura.gov.br.

Naranjo, S.E., Ellsworth, P.C. \& Frisvold, G.B. (2015). Economic Value of Biological Control in Integrated Pest Management of Managed Plant Systems. Annual Review of Entomology, 60(1): 621 - 645. doi: https://doi.org/10.1146/ annurev-ento-010814-021005.

Nauen, R., Ebbinghaus-Kintscher, U. \& Schmuck, R. (2001). Toxicity and nicotinic acetylcholine receptor interaction of imidacloprid and its metabolites in Apis mellifera (Hymenoptera: Apidae). Pest Management Science. 57(7): 577586. doi: https://doi.org/10.1002/ps.331.

Niva, C.C. \& Panizzi, A.R. (1996). Efeitos do cloreto de sódio no comportamento de Nezara viridula (L.) (Heteroptera: Pentatomidae) em vagens de soja. Anais da Sociedade Entomológica do Brasil. 25: 251-257.

Panizzi, A.R., Bueno, A.F. \& Silva, F.A.C. (2012). Insetos que atacam vagens e grãos. In: Bueno, $A$. de F., Pomari, A., Panizzi, A., Corrêa-Ferreira, B., Omoto, C., De Oliveira, C.M., Hoffmann-Campo, C.B., Ávila, C.J., Sosa-Gómez, D.R., Gazzoni, D.L., Hirose, E., Da Silva, F.A.C., Moscardi, F., Marcelino-Guimarães, F.C., Lorini, I., Corso, I.C., Salvadori, J.R., Oliveira, L.J., De Carvalho, M.C. da C., Fernandes, P.M., Bueno, R.C.O. de F., Roggia, S. \& Yano, S.A.C. Soja: manejo integrado de insetos e outros artrópodes-praga. pp. 335420. Brasil: Embrapa.

Panizzi, A.R., Kogan, M. \& Jepson, P. (2007). Nutritional ecology of plant feeding arthropods and IPM. In: Kogan, M. \& Jepson, P. Perspectives in Ecological Theory and Integrated Pest Management. pp. 170-222. Cambridge, UK: Cambridge University Press.

Pazini, J. de B., Padilha, A.C., Cagliari, D., Bueno, F.A., Rakes, M., Zotti, M.J., Martins, J.F. da S. \& Grützmacher, A.D. (2019). Differential impacts of pesticides on Euschistus heros (Hem.: Pentatomidae) and its parasitoid Telenomus podisi (Hym.: Platygastridae). Scientific Reports, 9(1): 6544. doi: https://doi. org/10.1038/s41598-019-42975-4

Pereira, A.I. de A., Ramalho, F. de S. \& Zanuncio, J.C. (2005). Susceptibility of Podisus nigrispinus
(Dallas) (Heteroptera: Pentatomidea) to gamma-cyhalothrin under laboratory conditions. Scientia Agricola. 62(5): 478482. doi: https://doi.org/10.1590/S010390162005000500012

Peterson, R.K.D., Higley, L.G. \& Pedigo, L.P. (2018). Whatever Happened to IPM? American Entomologist. 64(3): 146 - 150. doi: https:// doi.org/10.1093/ae/tmy049.

Pires, E.M., Pinto, R., Lacerda, M.C., Zanuncio, J.C. \& Fialho, M. do C.Q. (2006). Potencial reprodutivo horário do predador de lagartas desfolhadoras do eucalipto: Podisus nigrispinus (Heteroptera: Pentatomidae). Revista Árvore. 30(6): 10391044. doi: https://doi.org/10.1590/S010067622006000600020 .

Ramiro, Z.A., Batista Filho, A. \& Cintra, E.R.R. (2005). Eficiência do inseticida Actara Mix $110+220$ CE (thiamethoxam + cipermetrina) no controle de percevejos-pragas da soja. Arquivos Do Instituto Biológico. 72(2): 239-247.

Ramiro, Z.A., Batista Filho, A. \& Machado, L.A. (1986). Ocorrência de pragas e inimigos naturais em soja no Município de Orlândia, SP. Anais da Sociedade Entomológica do Brasil. 15 (2): 239-246.

Reis, T.C., Soares, M.A., Dos Santos, J.B., Dos Santos, C.A., Serrão, J.E., Zanuncio, J.C. \& Ferreira, E.A. (2018). Atrazine and nicosulfuron affect the reproductive fitness of the predator Podisus nigrispinus (Hemiptera: Pentatomidae). Anais Da Academia Brasileira de Ciências. 90(4): 3625-3633. doi: https:// doi.org/10.1590/0001-3765201820170748

Santos, M.F., Santos, R.L., Tomé, H.V.V., Barbosa, W.F., Martins, G.F., Guedes, R.N.C. \& Oliveira, E.E. (2016). Imidacloprid-mediated effects on survival and fertility of the Neotropical brown stink bug Euschistus heros. Journal of Pest Science. 89(1): 231-240. doi: https://doi. org/10.1007/s10340-015-0666-y

Sosa-Gómez, D.R., Takachi, C.Y. \& Moscardi, F. (1993). Determinação de sinergismo e suscetibilidade diferencial de Nezara viridula (L.) e Euschistus heros (F.) (Hemiptera: Pentatomidae) à inseticidas em mistura com cloreto de sódio. Anais da Sociedade Entomológica do Brasil. 22: 569-576. 
Tillman, P.G. \& Mullinix, B.G. (2004). Comparison of susceptibility of pest Euschistus servus and predator Podisus maculiventris (Heteroptera: Pentatomidae) to selected insecticides. Journal of Economic Entomology, 97(3): 800806. doi: https://doi.org/10.1603/0022 0493(2004)097[0800:cosope]2.0.co;2

Torres, J.B., \& Ruberson, J.R. (2004). Toxicity of thiamethoxam and imidacloprid to Podisus nigrispinus (Dallas) (Heteroptera: Pentatomidae) nymphs associated to aphid and whitefly control in cotton. Neotropical Entomology. 33(1): 99-106. doi: https://doi. org/10.1590/S1519-566X2004000100017

Tuelher, E.S., Da Silva, É.H., Rodrigues, H.S., Hirose, E., Guedes, R.N.C. \& Oliveira, E.E. (2018). Area-wide spatial survey of the likelihood of insecticide control failure in the neotropical brown stink bug Euschistus heros. Journal of Pest Science. 91(2): 849 -859. doi: https://doi. org/10.1007/s10340-017-0949-6.

Yarmolinsky, D.A., Zuker, C.S. \& Ryba, N.J.P. (2009). Common Sense about Taste: From Mammals to Insects. Cell, 139(2): 234-244. doi: https://doi. org/10.1016/j.cell.2009.10.001

Zanuncio, J.C., Molina-Rugama, A.J., Serrao, J. \& Pratissoli, D. (2001). Nymphal Development and Reproduction of Podisus nigrispinus (Heteroptera: Pentatomidae) fed with combinations of Tenebrio molitor (Coleoptera: Tenebrionidae) pupae and Musca domestica (Diptera: Muscidae) larvae. Biocontrol Science and Technology. 11(3): 331-337. doi: https:// doi.org/10.1080/09583150120055736.

Zanuncio, J.C., Mourão, S.A., Martínez, L.C., Wilcken, C.F., Ramalho, F.S., Plata-Rueda, A., Soares, M.A. \& Serrão, J. E. (2016). Toxic effects of the neem oil (Azadirachta indica) formulation on the stink bug predator, Podisus nigrispinus (Heteroptera: Pentatomidae). Scientific Reports. 6(1): 30261. doi: https:// doi.org/10.1038/srep30261 